\title{
De Han Moll-penning uitgereikt aan Ko Smal
}

Tijdens het NVMO-congres is de Han Moll-penning uitgereikt aan Ko Smal vanwege zijn verdiensten voor het medisch onderwijs in Nederland en België. Een jury onder voorzitterschap van prof. dr. H.J. Huisjes en verder bestaande uit prof. dr. Th.J. ten Cate en de ontvanger van de eerste Han Moll-penning, prof. dr. W.H.F.W. Wijnen, was unaniem tot deze voordracht gekomen. Tijdens het congresdiner reikte de voorzitter van de NVMO, prof. dr. H.J.M. van Rossum, de penning uit en zette hij Ko Smal in het zonnetje als 'de medisch-onderwijs-ankerman' van de huidige NVMO-leden.

Als blijk van hulde volgt hieronder de inhoud van het juryrapport.

"De jury heeft conform de opdracht gezocht onder personen 'die gedurende een langere periode een intensieve en creatieve bijdrage hebben geleverd aan de verbetering van het onderwijs en aan onderwijsontwikkeling; kandidaten met een landelijke uitstraling die door middel van publicaties, voordrachten en/of trainingen zorg gedragen hebben voor overdracht van kennis en ervaring naar een breed publiek'.

Dr. Jacobus Arnoldus Smal, geboren in 1940, na scholing in de filosofie en theologie in Antwerpen, Rome en Tilburg vervolgens opgeleid als psycholoog in Utrecht, werd in 1972 in Utrecht aangesteld als medewerker bij de nieuw opgerichte Vakgroep Onderzoek en Ontwikkeling van het Medisch Onderwijs van de faculteit geneeskunde. In een aaneen- gesloten periode van 29 jaar heeft hij het Utrechtse medisch onderwijs en diegenen die voor de ontwikkeling en de uitvoering ervan verantwoordelijk waren voortdurend van kwaliteitsadvies gediend. Daarnaast was zijn werk, veelal samen uitgevoerd en gepubliceerd met anderen, van betekenis voor het Nederlandse medische onderwijs in brede zin.

Bijzondere verdiensten van Ko Smal liggen op het terrein van simulatietechnieken, de bayesiaanse benadering van medische besliskunde, toetsing en selectie in het medisch onderwijs.

In 1974 verscheen bij uitgeverij Oosthoek, Scheltema en Holkema van Jaap Gerritsma en Ko Smal het boek 'Grensverschuivingen in het medisch onderwijs'. ${ }^{1}$ Dit boek kan met recht als het eerste medisch-onderwijskundige boek van betekenis in de Nederlandse taal worden gezien. Hierin wordt bijzondere aandacht besteed aan twee onderwerpen die toen revolutionair waren, en thans nog steeds actueel zijn: attitudevorming en simulatietechnieken. Het onderwerp van de schriftelijke patiëntensimulatie werd vervolgens onder meer in een tweede boek (met Van Es en Koopman) verder uitgewerkt. ${ }^{2}$

Voor het proefschrift 'De werkwijze van huisarts en internist' in 1982 (ook samen met Jaap Gerritsma) is met behulp van schriftelijke patiëntsimulatietechnieken het denkproces bij huisartsen en internisten onderzocht. ${ }^{3}$ Bij de analyses is gebruik gemaakt van destijds moderne statistische technieken. Het theorema van 
Bayes is pas later in de medische besliskunde gemeengoed geworden en ook de generaliseerbaarheidstheorie, door Ko Smal in 1982 toegepast voor de schatting van variantiecomponenten bij vaardigheidsmeting met simulatietechnieken, heeft pas jaren later in het medisch onderwijsonderzoek brede belangstelling gekregen.

Studietoetsing en selectie voor de medische opleiding hebben Ko Smal in latere jaren meer beziggehouden. Hij adviseerde veel over toetsing en nog altijd worden uitspraken van hem geciteerd als: 'wanneer de docent een toetsvraag zéér interessant noemt, ga er dan maar van uit dat hij te moeilijk is voor een toets en dus ongeschikt is'. Dat selectiemethoden bij de toelating weinig voorspellende waarde hebben voor het studiesucces heeft hij in een literatuuroverzicht getoond. ${ }^{4} 5$ Zijn open opstelling verklaart dat hij niettemin onlangs nog de waarde van assessmentcentertechnieken voor selectiedoeleinden bepleitte.

Ko Smal is een goed methodoloog en door frequente individuele begeleidingen, in cursussen en via het redactielidmaatschap van het Tijdschrift voor Medisch Onderwijs, heeft hij velen geholpen in het onderzoek van medisch onderwijs. Door zijn altijd bescheiden opstelling is hij zelf echter als een van de boegbeelden van de Nederlandse medische onderwijskunde te vaak onderbelicht geweest. Zijn reeds vroege, vervolgens langdurige en altijd kwalitatief hoogstaande inzet voor het Nederlandse medisch onderwijs is naar het oordeel van de jury het meer dan waard om gehonoreerd te worden met de Han Moll-penning."

Tot zover het juryrapport.

\section{H.J.M. van Rossum}

\section{Literatuur}

1. Gerritsma JGMG, Smal JA. Grensverschuivingen in het medisch onderwijs. Utrecht: Oosthoek, Scheltema en Holkema; 1974.

2. Es JC van, Gerritsma JGM, Koopman J, Smal JA. Simulaties van patienten in het onderwijs. Schriftelijke oefeningen in huisartsgeneeskunde. Utrecht: Bohn, Scheltema \& Holkema; 1977.

3. Gerritsma JGM, Smal JA, De werkwijze van huisarts en internist: een vergelijkend onderzoek met behulp van een interactieve patiëntensimulatie. Utrecht: Bunge; 1982.

4. Smal JA, Gerritsma JGM. Selectie. In: Metz JCM, Scherpbier AJJA, Vleuten CPM van der, redactie. Medisch onderwijs in de praktijk. Assen: Van Gorcum \& Comp. B.V.; 1995. p. 259-64.

5. Smal JA. Selectie met gewogen loting. Bulletin Medisch Onderwijs 1995;14(3):97-101. 